\title{
PENGARUH UKURAN PERUSAHAAN DAN PROFITABILITAS TERHADAP NILAI PERUSAHAAN DENGAN STRUKTUR MODAL SEBAGAI VARIABEL INTERVENING
}

(Studi pada Perusahaan Automotive and Allied Products di Bursa Efek Indonesia periode tahun 2010 - 2015)

Oleh :

Astohar

Dosen Sekolah Tinggi Ilmu Ekonomi Totalwin Semarang

\begin{abstract}
Abstrak
Model bertingkat atau structural faktor - faktor yang mempengaruhi nilai pelanggan yang dipengaruhi oleh ukuran perusahaan (size) dan profitabilitas (return on asset) secara langsung ataupun melalui struktur modal (debt to equity ratio). Obyek penelitian yang dipilih adalah pada perusahaan automotive dan allied products pada Bursa Efek Indonesia pada periode 2010 sampai dengan 2015. Pemilihan obyek pada perusahaan automotive di Bursa Efek Indonesia atas pertimbangan bahwa pada perusahaan automotive dan allied products tersebut perkembangan nilai perusahaan yang diproksi dengan price book to value yang lebih fluktuatif dibandingkan dengan sektor yang lainnya. Besar sampel yang dibutuhkan untuk penelitian ini adalah sebanyak 18 perusahaan yang secara berturut - turut masuk dalam Perusahaan automotive selama enam tahun berturut - turut dengan teknik pengambilan sampel menggunakan purposive non random sampling.

Alat analisis yang digunakan adalah uji persamaan regresi dengan model double regresi, yaitu pertama adalah pengaruh ukuran perusahaan dan profitabilitas terhadap struktur modal. Model regresi kedua adalah pengaruh ukuran perusahaan, profitabilitas dan struktur modal terhadap nilai perusahaan. Untuk memberikan hasil yang lebih baik sebelum dilakukan pengujian regresi data dilakukan pengujian normalitas, penyimpangan asumsi klasik, uji fit data dan pengujian hipotesis serta koefisien determinasi.

Hasil penelelitian menunjukkan bahwa struktur modal (debt to equity ratio), ukuran perusahaan (size) dan profitabilitas (return on aset) terbukti berpengaruh positif dan signifikan terhadap nilai perusahaan (price book to value). Ukuran perusahaan (size) juga terbukti berpengaruh positif dan signifikan terhadap struktur modal (debt to equity ratio). Profitabilitas (return on asset) tidak terbukti mempunyai pengaruh yang signifikan terahadap struktur modal
\end{abstract}

Kata Kunci : ukuran perusahaan, profitabilitas, struktur modal dan nilai perusahaan

\section{PENDAHULUAN}

Perkembangan bisnis otomotif di Indonesia juga semakin pesat baik untuk kepentingan pribadi maupun untuk motif bisnis. Menurut Alfredo (2012_ perusahaan otomotif mempunyai tiga tujuan yaitu pertama dalam jangka pendek bertujuan 
memperoleh laba secara maksimal. Tujuan kedua dalam jangka panjang bertujuan adalah memakmurkan pemilik dan pemegang saham. Tujuan yang ketiga adalah memaksimalkan nilai perusahaan yang dicerminkan pada harga saham dari perusahaan tersebut. Menurut Nofrita (2013) ketiga tujuan perusahaan tersebut berbeda pada penekanan yang ingin dicapai oleh masing-masing perusahaan berbeda antara yang satu dengan yang lainnya.

Dalam memaksimakan nilai perusahaan akan tergambar dari harga saham perusahaan bersangkutan. Semakin tinggi harga saham berarti semakin tinggi nilai perusahaan (Euis dan Taswan, 2002). Nilai perusahaan yang tinggi menjadi keinginan para pemilik perusahaan, sebab dengan nilai yang tinggi menunjukkan kemakmuran pemegang saham juga tinggi. Nilai perusahaan dapat mencerminkan kinerja perusahaan. hal ini dapat mempengaruhi persepsi investor terhadap perusahaan tersebut (Hermuningsih, 2012).

Nilai perusahaan merupakan konsep penting bagi investor, karena merupakan indikator bagi pasar menilai perusahaan secara keseluruhan (Nurlela dan Ishaluddin, 2008 dalam Alfredo, 2012). Lebih lanjut menurut Alfredo (2012) nilai perusahaan ini merupakan suatu harga yang bersedia untuk dibayar oleh calon pembeli jika perusahaan tersebut dijual. Nilai perusahaan merupakan cerminan dari penambahan dari jumlah ekuitas perusahaan dengan hutang perusahaan.

Nilai pasar dari suatu ekuitas perusahaan ditambah nilai pasar hutang dapat dikatakan juga sebagai nilai perusahaan. Penambahan dari jumlah ekuitas perusahaan dengan hutang perusahaan dapat mencerminkan nilai perusahaan. Nilai perusahaan dapat menggambarkan keadaan perusahaan, meningkatnya nilai perusahaan maka perusahaan akan dipandang baik oleh para calon investor, demikian pula sebaliknya nilai pemegang saham akan meningkat apabila nilai perusahaan meningkat yang ditandai dengan tingkat pengembalian investasi yang tinggi kepada pemegang saham.

Banyak proksi untuk mengukur nilai perusahaan, salah satunya adalah price to book value (PBV). Sehingga tingginya rasio Price to book value (PBV) menjadi keinginan para pemilik perusahaan. atau menjadi tujuan perusahaan, sebab akan meningkatkan kemakmuran para pemegang saham (Brigham dan Ehrhardt, 2006). Price to book value (PBV) merupakan perbandingan harga pasar dari suatu saham dengan nilai bukunya atau dengan kata lain seberapa besar suatu perusahaan mampu 
menciptakan nilai yang relatif terhadap jumlah modal yang diinvestasikan. Tingginya nilai PBV menunjukan nilai perusahaan adalah menjadi semakin baik (Martikarini, 2014).

Banyak faktor yang mempengaruhi nilai perusahaan (price book to value) diantaranya adalah, profitabilitas dan struktur modal (leverage ratio) secara langsung (Alfredo, 2012) yang diperkuat oleh Hermuningsih (2012) dan Hamidy (2014). Profitabilitas juga berpengaruh terhadap price book to value melalui struktur modal (leverage ratio). Model structural yang mempengaruhi nilai perusahaan melalui struktur modal (Hermuningsih, 2013).

Return on asset yang merupakan proksi dari profitabilitas merupakan rasio dari efektifitas manajemen perusahaan berdasarkan hasil pengembalian yang dihasilkan dari penjualan atau revenue (Hermuningsih, 2012). Profitabilitas dapat juga diartikan kemampuan perusahaan dalam memperoleh laba dalam kaitannya dengan hasil penjualan yang dikaitkan dengan total aktiva maupun modal sendiri (Sartono, 2009). Profitabilitas mempunyai pengaruh yang positif terhadap struktur modal (Hermuningsih, 2012) dan dapat juga berdampak pada nilai perusahaan (Alfredo, 2012). Kemampuan perusahaan dalam meningkatkan keuantungan akan berdampak pada penilaian positif dari masyarakat kepada perusahaan tersebut (Nofrita, 2013 dan Hermuningsih, 2013).

Ukuran perusahaan (size) yang diproksi dengan total asset adalah seberapa besar asset yang dimiliki oleh perusahaan (Pratama dan Wiksuana, 2016). Ukuran perusahaan yang diukur dengan Log dari total asset mempunyai pengaruh positif terhadap struktur modal perusahaan (Semakin besar perusahaan akan berdampak pada tingkat kepercayaan perusahaan untuk meningkatkan struktur modalnya (Hermuningsih, 2012). Selain berdampak pada struktur modal, ukuran perusahaan juga mempuyai dampak positif terhadap nilai perusahaan (Pratama dan Wiksuana, 2016). Kemampuan perusahaan dalam mengakomodir sektor bisnis mempunyai dampak pada penilaian masyarakat terhadap perusahaan berkaitan dengan nilai perusahaan (Gill dan Obradovich, 2012). Hal berbeda ditunjukkan oleh Naceur dan Goaied (2002) memiliki hasil yang bertentangan, dimana hasil penelitian menyatakan bahwa ukuran perusahaan berpengaruh negatif dan signifikan terhadap nilai perusahaan. 
Berdasarkan latar belakang diatas dapat ditarik permasalahan yaitu adanya gap dari beberapa penelitian yang dilakukan oleh Gill dan Obradovich (2012) berkenaan dengan model structural faktor - faktor yang mempengaruhi nilai perusahaan yang melalui struktur modal, hal ini berbeda dengan penelitian yang dilakukan oleh Naceur dan Goaid (2002) yang menyatakan bahwa ukuran perusahaan mempunyai pengaruh yang negatif terhadap nilai perusahaan.

\section{LANDASAN TEORITIS}

\section{Pecking Order Theory (POT) dan Trade- Off Theory (TOT)}

Teori lain dari struktur modal yaitu pecking order theory (POT) yang dikemukakan oleh Myers dan Maljuf pada tahun 1984 (dalam Joni dan Lila, 2010). Teori ini secara ringkas menjelaskan mengenai keputusan pendanaan yang menyatakan bahwa perusahaan cenderung menggunakan sumber pendanaan internal (retained earnings) terlebih dahulu yaitu dari laba yang ditahan dan depresiasi, daripada menggunakan dana eksternal (hutang saham) dari aktivitas pendanaan. Hutang yang merupakan sumber pendanaan eksternal, baru digunakan oleh perusahaan jika sudah tidak memiliki dana internal yang tidak mencukupi dan memadai. Apabila dana eksternal lebih dibutuhkan maka perusahaan akan lebih cenderung menggunakan hutang dari pada ekuitas (Joni dan Lina, 2010).

Sejumlah pendapat terdahulu mengarah pada perkembangan yang disebut dengan Teori trade-off dari utang. Perusahaan menyeimbangkan manfaat dari pendanaan dan utang dengan suku bunga dan biaya kebangkrutan yang lebih tinggi (Brigham dan Houston, 2011). Teori Trade-Off mempunyai argumen dimana perusahaan menyeimbangkan manfaat dari pendanaan dengan hutang (perlakuan pajak perseroan yang menguntungkan) dengan suku bunga dan biaya kebangkrutan yang lebih tinggi dalam penentuan struktur modal (Wardani, 2015).

\section{Nilai Perusahaan}

Penilaian terhadap suatu perusahaan ditunjukkan dengan laporan keuangan perusahaan, khususnya neraca yang berisi informasi keuangan masa lalu. Pihak di luar perusahaan berpendapat bahwa nilai suatu perusahaan ditunjukkan dengan nilai saham perusahaan. Nilai perusahaan sangat penting untuk peningkatan kemakmuran pemegang saham (Bringham dan Houston, 2011). Nilai perusahaan yang tinggi menjadi keinginan para pemilik perusahaan, karena mampu menunjukkan 
kemakmuran pemegang saham juga tinggi. Nilai perusahaan dicerminkan oleh harga pasar dari saham yang merupakan indikasi dari keputusan investasi. pendanaan (financing) dan manajemen asset (Hermuningsih, 2012).

Menurut Sujoko dan Soebiantoro (2007) nilai perusahaan merupakan persepsi investor terhadap tingkat keberhasilan perusahaan yang terkait erat dengan harga sahamnya. Harga saham yang digunakan untuk mengukur nilai adalah harga penutupan (clossing price) dan merupakan harga yang terjadi pada saat saham diperdagangkan di pasar (Fakhruddin dan Hadianto, 2011). Tingginya harga saham yang tinggi membuat nilai perusahaan juga semakin tinggi kepercayaan pasar adalah pada prospek perusahaan tersebut untuk masa - masa mendatang (Hermuningsih, 2013).

Penilaian terhadap suatu perusahaan ditunjukkan dengan laporan keuangan perusahaan, khususnya neraca yang berisi informasi keuangan masa lalu. Pihak di luar perusahaan berpendapat bahwa nilai suatu perusahaan ditunjukkan dengan nilai saham perusahaan. Nilai perusahaan diciptakan oleh perusahaan melalui kegiatan perusahaan dari waktu ke waktu agar mencapai nilai perusahaan yang maksimum di atas nilai buku (Nofrita, 2013).

Nilai perusahaan dalam penelitian ini diukur dengan price book value ratio (PBV) (Brigham dan Houston, 2011). Rasio price book value (PBV) memberikan gambaran tingkat kemampuan perusahaan menciptakan nilai relatif terhadap jumlah modal yang diinvestasikan. Peningkatan PBV atau PBV yang tinggi mencerminkan harga saham yang tinggi dibandingkan nilai buku per lembar saham. Keberhasilan perusahaan dalam menciptakan nilai perusahaan tersebut tentunya memberikan harapan kepada pemegang saham berupa keuntungan yang lebih besar pula (Sartono, 2009).

\section{Struktur Modal}

Struktur modal adalah proporsi dalam upaya pemenuhan kebutuhan pembelanjaan perusahaan dengan sumber pendanaan jangka panjang yang berasal dari dana internal dan dana eksternal. Struktur modal merupakan perimbangan atau perpaduan antara modal asing dengan modal sendiri (Husnan dan Pudjiastuti, 2012). Struktur permodalan merupakan keputusan untuk memilih sumber pembiayaan atau komposisi pemilihan atas pendanaan yang merupakan perbandingan dalam 
menentukan pemenuhan kebutuhan belanja perusahaan dimana dana yang diperoleh merupakan kombinasi dari sumber yang berasal dari dana jangka panjang yang terdiri dari dua sumber utama yaitu berasal dari dalam dan luar perusahaan (Rodoni dan Ali, 2010).

Struktur keuangan mencerminkan perimbangan baik dalam artian absolut maupun relatif antara keseluruhan modal asing dengan jumlah modal sendiri (Riyanto, 2010). Struktur modal merupakan kombinasi utang dan ekuitas dalam struktur keuangan jangka panjang perusahaan, tidak seperti rasio utang yang hanya menggambarkan target komposisi utang dan ekuitas dalam jangka panjang pada suatu perusahaan (Arifin, 2005 dalam Yusrianto, 2013).

Struktur modal adalah perbandingan antara modal eksternal jangka panjang dengan modal sendiri. Aspek yang penting bagi setiap perusahaan karena mempunyai efek secara langsung terhadap komposisi finansial dari perusahaan. Perusahaan yang memiliki aktiva berwujud cukup besar akan mempunyai kecenderungan menggunakan hutang dalam proporsi yang lebih besar pula (Hermuningsih, 2012). Kebijakan hutang yang diukur dengan debt to equity ratio (DER) berpengaruh positif dan signifikan terhadap price book value (Sujoko dan Soebiantoro, 2007). Hasil ini diperkuat oleh penelitian dari Hermuningsih (2013) ada pengaruh yang signifkan antara struktur modal terhadap nilai perusahaan. Berdasarkan hasil penelitian tersebut diajukan hipotesis keenam $\left(\mathrm{H}_{7}\right)$ yaitu sebagai berikut :

$\mathrm{H}_{1}$ : Struktur modal berpengaruh positif dan signifikan terhadap nilai perusahaan

\section{Ukuran Perusahaan}

Ukuran perusahaan adalah besar kecilnya perusahaan dapat dilihat dari besarnya nilai equity, nilai penjualan, atau nilai aktiva (Riyanto, 2008). Ukuran perusahaan adalah besar kecilnya perusahaan dapat diukur dengan total aktiva/ besar harta perusahaan dengan menggunakan perhitungan nilai logaritma total aktiva. Dari berbagai definisi tersebut, maka dapat disimpulkan bahwa ukuran perusahaan merupakan ukuran dari besar atau kecilnya suatu perusahaan yang dapat dilihat dari berbagai skala dan ukuran perusahaan dapat diukur berdasarkan pada total aktiva perusahaan dan dapat menentukan tingkat kemudahan untuk memperoleh dana yang berasal dari pasar modal dalam suatu perusahaan. 
Suatu perusahaan yang besar dan mapan (stabil) akan lebih mudah untuk ke pasar modal (Weston dan Brigham, 2000). Kemudahan untuk ke pasar modal maka berarti fleksibilitas bagi perusahaan besar lebih tinggi serta kemampuan untuk mendapatkan dana dalam jangka pendek juga lebih besar daripada perusahaan kecil. Ukuran perusahaan secara langsung mencerminkan tinggi rendahnya aktivitas operasi suatu perusahaan.Pada umumnya semakin besar suatu perusahaan maka akan semakin besar pula aktivitasnya. Ukuran perusahaan juga dapat dikaitkan dengan besarnya kekayaan yang dimiliki oleh perusahaan (Fidyati, 2003).

Variabel size berpengaruh positif dan signifikan terhadap nilai perusahaan (Soliha dan Taswan, 2002). Perusahaan besar dapat mengakses dengan mudah ke pasar modal.Kemudahan untuk mengakses ke pasar modal berarti perusahaan memiliki fleksibilitas dan kemampuan untuk mendapatkan dana. Karena kemudahan aksebilitas ke pasar modal dan kemampuannya untuk memunculkan dana lebih besar. Berdasarkan argument tersebut dapat dirumuskan hipotesis kedua $\left(\mathrm{H}_{2}\right)$ sebagai berikut :

$\mathrm{H}_{2}$ : Variabel likuiditas mempunyai pengaruh yang negative dan signifikan terhadap struktur modal

Ukuran perusahaan (Firm Size) menggambarkan besar kecilnya suatu perusahaan, perusahaan yang lebih besar akan lebih mudah memperoleh pinjaman dibandingkan perusahaan kecil (Chen dan Strange, 1998 dalam Ichwan dan Widyawati, 2015). Perusahaan yang lebih besar cenderung memiliki tingkat Leverage yang lebih tinggi dibandingkan dengan perusahaan yang lebih kecil, dimana tingkat kebangkrutanya lebih rendah daripada perusahaan kecil, semakin besar suatu perusahaan, ada kecenderungan untuk menggunakan jumlah pinjaman yang lebih besar dibandingkan dengan perusahaan kecil. Perusahaan yang memiliki ukuran perusahaan yang besar lebih banyak menggunakan hutang sehingga memperbesar struktur modal, sedangkan perusahaan yang memiliki ukuran perusahaan yang kecil, lebih sedikit menggunakan hutang sehingga memperkecil struktur modal perusahaan Ichwan dan Widyawati, 2015). Beberapa pernyataan di atas dapat disimpulkan bahwa ukuran perusahaan mempunyai hubungan yang positif dengan struktur modal. Berdasarkan hasil penelitian diatas dapat diajukan hipotesis ketiga $\left(\mathrm{H}_{3}\right)$ yaitu sebagai berikut : 
$\mathrm{H}_{3}$ : Variabel Ukuran Perusahaan mempunyai pengaruh yang positif dan signifikan terhadap nilai perusahaan

\section{Profitabilitas}

Profitabiitas adalah kemampuan perusahaan dalam menghasilkan laba (Ayuningtyas dan Kurnia, 2013). Profitabilitas merupakan kemampuan perusahaan untuk menghasilkan keuntungan dan mengukur tingkat efisiensi operasional dan efisiensi dalam menggunakan harta yang dimilikinya (Chen, 2004, dalam Hermuningsih, 2013). Profitabilitas dapat dijadikan cerminan untuk mengukur kinerja manajemen dalam menjalankan usaha (perusahaan). Indikator profitabilitas dapat berbagai macam seperti : laba operasi, laba bersih, tingkat pengembalian investasi/aktiva dan tingkat pengembalian ekuitas pemilik (Petronila dan Mukhlasin, 2003 dalam Hermuningsih, 2013).

Profitabilitas adalah kemampuan perusahaan memperoleh laba dalam hubungannya dengan penjualan, total aktiva, maupun modal sendiri (Wulandari. 2010). Peningkatan profitabilitas menunjukkan adanya prospek perusahaan dari perusahaan tersebut, sehingga investor akan merespon sebagai sinyal positif dan nilai perusahaan akan meningkat (Sujoko dan Soebiantoro, 2007, dalam Apsari dkk, 2015). Profitabilitas menjadi dasar penilaian kondisi keuangan dalam menghasilkan laba suatu perusahaan (Apsari dkk, 2015).

Pada penelitian ini return on investment (ROI) ditetapkan sebagai proksi dari variabel profitabilitas. Pertimbangan ini didasarkan pada rasio ROI dapat mengukur efektifitas perusahaan dalam menghasilkan laba bersih dengan menggunakan aset yang dimiliki untuk menghasilkan laba tersebut. Return on investment dapat menjadi indikator keberhasilan perusahaan di pemandangan investor (Dwiaji, 2011). Return on investment menunjukkan kemampuan perusahaan dalam menghasilkan laba dari aset yang digunakan atau diinvestasikan dalam satu periode akuntansi (Fakhruddin dan Hadianto, 2011).

Perusahaan yang memiliki tingkat keuntungan lebih tinggi akan menggunakan utang yang relatif lebih kecil dibandingkan perusahaan dengan keuntungan yang rendah. Tingkat keuntungan yang tinggi memungkinkan mereka untuk memperoleh sebagian besar pendanaan dari laba ditahan (Amalia dan Alfianto, 
2014). Perusahaan akan cenderung memilih laba ditahan untuk membiayai sebagian besar kebutuhan pendanaan.

Hasil penelitian dari Yusrianti (2013) menunjukkan bahwa ada pengaruh yang negative dan signifikan antara profitabilitas terhadap struktur modal. Hal ini diperkuat dari penelitian Hermuningsih (2013) dan Resino dkk (2015) yaitu meningkatkan profitabilitas akan menurunkan penggunaan rasio hutang. Berdasarkan argumen tersebut dapat diajukan hipotesis keempat $\left(\mathrm{H}_{4}\right)$ yaitu sebagai berikut :

$\mathrm{H}_{4}$ : Profitabilitas berpengaruh negative dan signifikan terhadap struktur modal

Peningkatan kemampuan perusahaan dalam menghasilkan laba akan berdampak pada peningkatan harga saham (Nofrita, 2013). Peningkatan harga saham merupakan cerminan nilai perusahaan yang baik bagi investor. Peningkatan nilai pemegang saham dengan nilai perusahaan meningkat yang ditandai dengan tingkat pengembalian investasi yang tinggi kepada pemegang saham. Tingkat pengembalian investasi kepada pemegang saham tergantung pada laba yang dihasilkan perusahaan. (Hermuningsih, 2013). Hasil penelitian Alfredo, dkk (2012) menunjukkan bahwa ada pengaruh yang positif dan signifikan antara profitabilitas terhadap nilai perusahaan. Hal ini diperkuat oleh Wahyuni dkk (2013) meningkatkan rasio profitabilitas akan meningkatkan nilai perusahaan. Berdasarkan hasil penelitian tersebut diajukan hipotesis kelima $\left(\mathrm{H}_{5}\right)$ yaitu sebagai berikut: $\mathrm{H}_{5}$ : Profitabilitas berpengaruh positif dan signifikan terhadap nilai perusahaan

\section{Kerangka Pikir}

Nilai perusahaan sangat penting untuk peningkatan kemakmuran pemegang saham. Struktur modal mempunyai peranan dalam meningkatkan kemakmuran atau nilai perusahaan. Penentuan struktur modal yang merupakan bauran antara hutang dan ekuitas bertujuan untuk mengoptimalkan nilai dari suatu perusahaan. Optimalnya struktur modal dari suatu perusahaan adalah memaksimumkan harga saham perusahaan. Sejumlah faktor mempengaruhi struktur modal dan nilai perusahaan adalah likuiditas, peluang pertumbuhan dan tingkat profitabilitas.

Kerangka pikir dalam penelitian ini adalah sebagai berikut : 


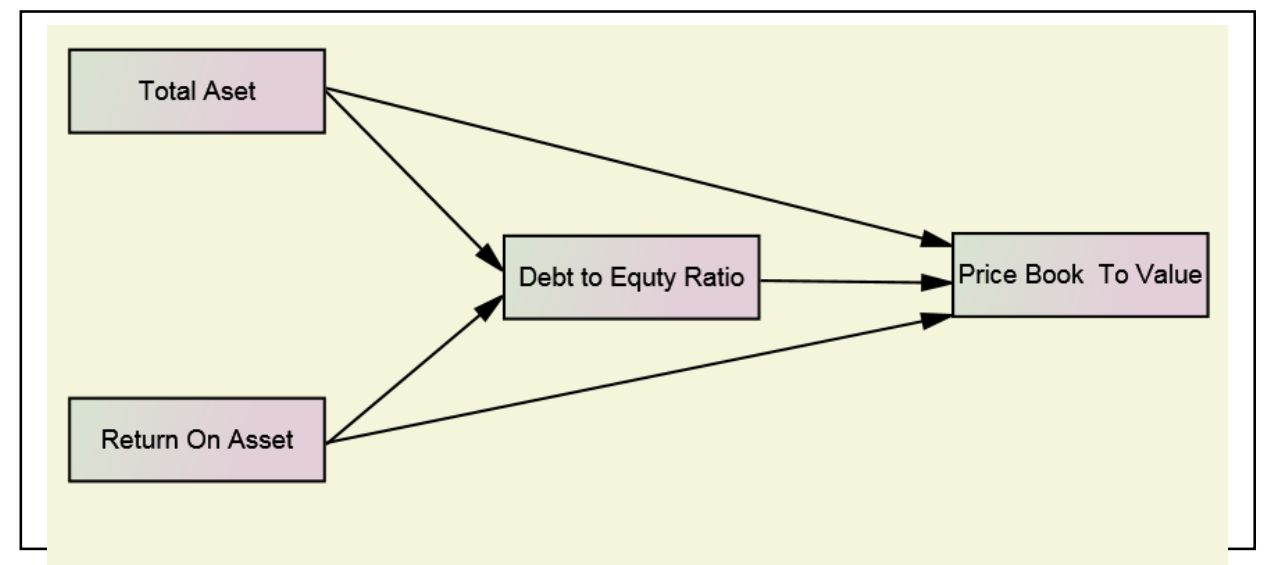

MET

\section{Defini}

zndekatan

kuanti

didalam

pembi

berikut :

\begin{tabular}{|c|c|c|c|}
\hline \multicolumn{4}{|l|}{$\begin{array}{l}\text { Variab } \\
\text { Bebas }\end{array}$} \\
\hline \multicolumn{4}{|l|}{ Ukurar } \\
\hline \multicolumn{4}{|l|}{$\overline{\text { Profita }}$} \\
\hline & & $\begin{array}{l}\text { dihasilkan manajemen } \\
\text { atas total aset }\end{array}$ & \\
\hline $\begin{array}{l}\text { Struktur } \\
\text { Modal } \\
\text { (Intervening) }\end{array}$ & DER & $\begin{array}{l}\text { Hubungan antara total } \\
\text { hutang dengan modal } \\
\text { sendiri }\end{array}$ & $\mathrm{DER}=\frac{\text { Total Hutang }}{\text { Modal Sendiri }}$ \\
\hline $\begin{array}{l}\text { Nilai } \\
\text { Perusahaan } \\
\text { (variable } \\
\text { terikat) }\end{array}$ & PBV & $\begin{array}{lr}\text { Persepsi } & \text { investor } \\
\text { terhadap } & \text { tingkat } \\
\text { keberhasilan perusahaan } \\
\text { dalam } & \text { mengelola } \\
\text { sumber daya pada tahun } \\
\text { berjalan }\end{array}$ & $\mathrm{PBV}=\frac{\text { Harga Pasar Per lbr shm }}{\text { Nilai Buku per Lbr shm }}$ \\
\hline
\end{tabular}




\section{Populasi dan Sampel}

Populasi dalam penelitian ini adalah seluruh perusahaan dalam kelompok Automotif dan Allied Products yang telah terdaftar di Bursa Efek Indonesia 2010 2015. Pemilihan sampel dilakukan dengan menggunakan metode purposive sampling dan menghasilkan sampel 18 perusahaan yang masuk perusahaan Automotif dan Allied Products. Pengumpulan data menggunakan panel, sehingga selama 6 tahun periode penelitian jumlah observasi sebanyak 18 perusahaan dan 108 observasi. Setelah dilakukan pengecekan terdapat perusahaan yang tidak memiliki data secara lengkap secara 6 tahun berturut - turut serta ada 2 perusahaan yang listing diatas tahun 2013 dan 1 perusahaan tidak lengkap, sehingga tidak dapat digunakan sebagai sampel. Setelah melalui tahapan ini data yang bisa diolah adalah sebanyak 96 observasi

\section{Jenis dan Metode Pengumpulan Data}

Jenis data yang digunakan dalam penelitian ini adalah data kuantitatif berupa laporan keuangan publikasi tahunan yang diterbitkan oleh Indonesia Capital Market Directory (ICMD) dari periode tahun 2010 sampai tahun 2015. Sumber data yang digunakan ini diperoleh melalui penelusuran dari media internet dari www. idx.go.id dan website resmi PT. Bursa Efek Indonesia. Metode pengumpulan data yang digunakan yaitu melalui studi pustaka dari direktori perusahaan go publik dan situs resmi tiap perusahaan. idx.go.id. serta situs - situr resmi lainnya yang dijadikan sampel.

\section{Alat Analisis Data}

\section{Uji Normalitas dan Penyimpangan Asumsi Klasik}

Uji normalitas bertujuan untuk menguji apakah dalam model regresi. variabel pengganggu atau residual memiliki distribusi normal. Seperti diketahui bahwa uji $t$ dan F mengasumsikan bahwa nilai residual mengikuti distribusi normal. Pengujian normalitas menggunakan grafik dan non parametric kolmogorof smirnov (Ghozali, 2013).

Selain memenuhi criteria normal. model juga harus terbebas dari penyimpangan asumsi klasik yang terdiri dari uji multikolinearitas ditandai dengan nilai tolerance lebih diatas 0,1 dan VIF dibawah 10. Penyimpangan uji heteroskedastisitas menggunakan pendekatan grafik scaterplott dan uji glejsyer. Pengujian penyimpangan autokorelasi dengan menggunakan nilai durbin Watson (Ghozali, 2013). 


\section{Uji Persamaan Regresi Ganda}

Analisis regresi linier berganda adalah pengaruh secara linier antara dua atau lebih variabel independen dengan satu variabel dependen yang digunakan untuk memprediksi atau meramalkan suatu nilai variabel dependen berdasarkan variabel independen. Sebelum melakukan estimasi yang tidak biasa dengan analisis regresi, perlu dilakukan uji t dan uji Fit data yaitu pengujian antar variabel bebas supaya tidak terjadi multikolinieritas, heteroskedastisitas, normalitas, dan autokorelasi (Priyatno, 2012).

Persamaan regresi pada penelitian ini terdapat dua model. yaitu sebagai berikut :

$I=\beta_{0}+\beta_{1} X_{1}+\beta_{2} X_{2}+e$

$\mathrm{Y}=\beta_{0}+\beta_{1} X_{1}+\beta_{2} X_{2}+\beta_{4} I+e$

Dimana :

I : struktur modal

$\mathrm{X}_{1}$ : ukuran perusahaan

$\mathrm{X}_{3}$ : profitabilitas

Y : nilai perusahaan

\section{Koefisien Determinasi}

Koefisien determinasi pada intinya untuk mengukur seberapa jauh kemampuan model dalam menerangkan variasi variabel dependen. Koefisien determinan pada penelitian ini digunakan untuk melihat berapa persen dari variasi variabel terikat dijelaskan variabel bebas. (Ghozali, 2013).

\section{HASIL DAN PEMBAHASAN}

\section{Analisis Deskriptif}

Deskripsi tentang rasio-rasio penelitian yang berupa total asset yang rataratanya adalah sebesar 19698568,7. Berdasarkan rata - rata, perusahaan masuk dalam kategori yang sedang. Berdasarkan data yang diperoleh total asset terendah selama periode penelitian adalah sebesar 150937 yaitu PT. Multi Prima Sejahtera, Tbk pada tahun 2010 dan yang tertinggi adalah pada sebesar 7245435000 pada PT. Astra International, Tbk pada tahun 2015.

Pada variabel return on asset (ROA) ini menunjukkan bahwa berdasarkan rata - rata perusahaan masuk dalam kategori yang kurang bagus, hal ini ditandai 
dengan rata - rata return on asset (ROA) masih dikisaran 7,31\% (sehat lebih dari 1,5 $\%)$. Return on asset (ROA) terendah selama periode penelitian adalah sebesar - 5,62 pada PT. Multi Prima Sejahtera, Tbk pada tahun 2014 dan tertinggi adalah sebesar 23,39 pada PT. Selamat Sempurna pada tahun 2014.

Pada variabel debt to equity ratio (DER) ini menunjukkan bahwa berdasarkan rata - rata perusahaan masuk dalam kategori yang kurang bagus, hal ini ditandai dengan rata - rata debt to equity ratio (DER) masih dikisaran 1,44. Debt to equity ratio (DER) terendah selama periode penelitian adalah sebesar 0,23 yaitu pada PT. Indo Kordsa, Tbk pada tahun 2010 dan tertinggi adalah sebesar 15,46 yaitu pada PT. INtraco Penta, Tbk pada tahun 2013.

Pada variabel price book to value $(P B V)$ ini menunjukkan bahwa berdasarkan rata - rata perusahaan masuk dalam kategori yang kurang bagus, hal ini ditandai dengan rata - rata price book to value $(P B V)$ masih dikisaran 2,82. price book to value $(P B V)$ terendah selama periode penelitian adalah sebesar 0,12 yaitu pada PT. Indospring, Tbk pada tahun 2015 dan tertinggi adalah yaitu sebesar 39,50 pada PT. Astra International, Tbk pada tahun 2011.

\section{Uji Penyimpangan Asumsi Klasik}

Berdasarkan hasil perhitungan dengan program SPSS diperoleh hasil bahwa model terbebas dari penyimpangan asumsi klasik sebagai berikut

a. Model penelitian pada awalnya tidak terdistribusi secara normal, diindikasikan ada data yang ekstrim. Direkomendasikan untuk membuang data sebanyak 6 observasi. Setelah 6 data dikeluarkan model terdisitribusi secara normal, yang ditandai dengan grafik normal P - P Plot Regression yang titik-titik pada grafik menyebar disekitar garis diagonal, serta penyebarannya mengikuti arah garis diagonal. Selain itu pada grafik Histogram yang menunjukkan sebaran data mendekati garis normal. Untuk memperkuat analisis digunakan metode statistik yang ditandai dengan nilai uji kolmogorof smirnov sebesar 0,051 (diatas 0,05)

b. Terbebas penyimpangan Multikolinearitas, yaitu dibuktikan dengan nilai tolerance diatas 0,1 yaitu masing - masing sebesar 0,$991 ; 0,887$ dan 0,890 dan nilai variance inflation factor (VIF) dibawah 10 yaitu masing - masing 1,009; 1,128 dan 1,124. Selain itu nilai koefisien korelasi antar variabel bebas adalah lemah 
yaitu sebesar - 0,$066 ; 0,330$ dan - 0,088 yang mana nilai tersebut masih dibawah 0,7 .

c. Terbebas penyimpangan heteroskedastisitas yang ditandai grafik sccaterplot (lampiran) tidak membentuk pola khusus atau gambarnya menyebar.

d. Terbebas dari penyimpangan autokorelasi, yaitu ditandai dengan nilai durbin Watson sebesar 2,410 yang mana nilai tersebut masuk dalam areal tanpa kesimpulan.

\section{Uji Fit Data}

Hasil uji fit data diperoleh nilai F hitung sebesar 19,333 serta nilai probabilitas sebesar 0,000. Hasil perbandingan menunjukkan bahwa nilai probabilitas $(0,000)<\alpha(0,05)$ dan F hitung lebih besar dari F tabel $(19,333>2,45)$. Sehingga dapat dikatakan bahwa permodelan yang dibangun memenuhi kriteria fit.

\section{Persamaan Regresi Berganda dan Pengujian Hipotesis}

Berdasarkan tabel diatas diperoleh persamaan regresi sebagai berikut :

$\mathrm{PBV}=-2,362+0,451 \log \mathrm{Ta}+0,129 \mathrm{ROA}+0,124$ DER

Nilai konstanta pada penelitian ini diperoleh nilai - 2,362 yang dapat diartikan bahwa tanpa adanya perubahan dari variabel bebas atau variabel TA, ROA dan DER maka nilai perusahaan (price book to value) pada Perusahaan mengalami penurunan.

Struktur modal (debt to equity ratio) perusahaan automotive yang go public di Indonesia mempunyai pengaruh positif terhadap nilai perusahaan dengan koefisien regresi sebesar 0,124 . Hal ini dapat diartikan setiap adanya peningkatan debt to equity ratio maka nilai perusahaan pada perusahaan automotive yang go publik di Indonesia akan mengalami peningkatan, atau sebaliknya. Hipotesis diterima, karena dibuktikan dengan nilai probabilitas (sig) sebesar 0,038 yang mana nilai tersebut masih di bawah 0,05 .

Hipotesis $1\left(\mathrm{H}_{1}\right)$ yang diajukan adalah debt to equity ratio pada Perusahaan berpengaruh posifit dan signifikan terhadap nilai perusahaan. Hasil pengujian menunjukkan bahwa hipotesis $1\left(\mathrm{H}_{1}\right)$ terbukti signifikan, hal ini dapat ditunjukkan dengan nilai t hitung sebesar 2,106 yang lebih besar dari t tabel $(1,96)$ serta nilai probabilitas $(0,038)<\alpha(0,05)$. Sehingga dapat dijelaskan bahwa debt to equity ratio Perusahaan terbukti berpengaruh positif dan signifikan terhadap nilai perusahaan atau 
semakin besar debt to equity ratio maka akan meningkatkan nilai perusahaan automotive yang go publik di Indonesia.

Ukuran perusahaan (size) perusahaan automotive yang go publik di Indonesia tidak mempunyai pengaruh positif dan signifikan terhadap struktur modal (debt to equity ratio) dengan koefisien regresi sebesar 0,172. Hal ini dapat diartikan bahwa setiap peningkatan ukuran perusahaan maka struktur modal pada perusahaan automotive yang go publik di Indonesia tidak selamanya mengalami peningkatan. Hipotesis ditolak, karena dibuktikan dengan nilai probabilitas (sig) sebesar 0,536 yang mana nilai tersebut di atas 0,05 .

Hipotesis $2\left(\mathrm{H}_{2}\right)$ yang diajukan adalah ukuran pada perusahaan berpengaruh positif dan tidak signifikan terhadap struktur modal (DER). Hasil pengujian menunjukkan bahwa hipotesis $2\left(\mathrm{H}_{2}\right)$ tidak terbukti, hal ini dapat ditunjukkan dengan nilai t hitung sebesar 0,621 yang kurang dari t tabel $(1,960)$ serta nilai probabilitas $(0,536)>\alpha(0,05)$. Sehingga dapat dijelaskan bahwa ukuran perusahaan (size) tidak terbukti berpengaruh positif dan signifikan terhadap struktur modal (DER) atau semakin besar ukuran perusahaan maka tidak mampu meningkatkan stuktur modal (DER), hal ini ditandai dengan hipotesis yang tidak terbukti.

Ukuran perusahaan (size) perusahaan automotive yang go publik di Indonesia mempunyai pengaruh positif terhadap nilai perusahaan dengan koefisien regresi sebesar 0,451. Hal ini dapat diartikan bahwa setiap peningkatan ukuran perusahaan (size) maka nilai perusahaan pada perusahaan automotive yang go publik di Indonesia mengalami peningkatan. Hipotesis diterima, karena dibuktikan dengan nilai probabilitas (sig) sebesar 0,004 yang mana nilai tersebut di bawah 0,05.

Hipotesis $3\left(\mathrm{H}_{3}\right)$ yang diajukan adalah ukuran perusahaan (size) pada perusahaan berpengaruh positif dan signifikan terhadap nilai perusahaan. Hasil pengujian menunjukkan bahwa hipotesis $2\left(\mathrm{H}_{2}\right)$ terbukti, hal ini dapat ditunjukkan dengan nilai $\mathrm{t}$ hitung sebesar 2,952 yang lebih dari t tabel $(1,960)$ serta nilai probabilitas $(0,004)<\alpha(0,05)$. Sehingga dapat dijelaskan bahwa ukuran perusahaan perusahaan terbukti berpengaruh positif dan signifikan terhadap nilai perusahaan atau semakin besar ukuran perusahaan maka akan mampu meningkatkan nilai perusahaan. 
Profitabilitas (return on aset) perusahaan automotive yang go publik di Indonesia mempunyai pengaruh negatif terhadap struktur modal (debt to equity ratio) dengan koefisien regresi sebesar - 0,107. Hal ini dapat diartikan bahwa setiap peningkatan return on aset (ROA) maka struktur modal pada perusahaan automotive yang go publik di Indonesia mengalami penurunan. Hipotesis diterima, karena dibuktikan dengan nilai probabilitas (sig) sebesar 0,002 yang mana nilai tersebut di bawah 0,05 .

Hipotesis $4\left(\mathrm{H}_{4}\right)$ yang diajukan adalah return on aset (ROA) pada perusahaan berpengaruh negatif dan signifikan terhadap struktur modal (DER). Hasil pengujian menunjukkan bahwa hipotesis $4\left(\mathrm{H}_{4}\right)$ terbukti, hal ini dapat ditunjukkan dengan nilai t hitung sebesar - 3,263 yang kurang dari - t tabel (- 1,960) serta nilai probabilitas $(0,002)<\alpha(0,05)$. Sehingga dapat dijelaskan bahwa return on asset (ROA) perusahaan terbukti berpengaruh negatif dan signifikan terhadap struktur modal (DER) atau semakin besar return on aset maka akan mampu menurunkan stuktur modal (DER), hal ini ditandai dengan hipotesis yang terbukti.

Profitabilitas (return on aset) perusahaan automotive yang go publik di Indonesia mempunyai pengaruh positif terhadap nilai perusahaan (price book to value ratio) dengan koefisien regresi sebesar 0,129 . Hal ini dapat diartikan bahwa setiap peningkatan return on aset (ROA) maka nilai perusahaan pada perusahaan automotive yang go publik di Indonesia mengalami peningkatan. Hipotesis diterima, karena dibuktikan dengan nilai probabilitas (sig) sebesar 0,000 yang mana nilai tersebut di bawah 0,05 .

Hipotesis $5\left(\mathrm{H}_{5}\right)$ yang diajukan adalah return on aset (ROA) pada perusahaan berpengaruh positif dan signifikan terhadap nilai perusahaan. Hasil pengujian menunjukkan bahwa hipotesis $5\left(\mathrm{H}_{5}\right)$ terbukti, hal ini dapat ditunjukkan dengan nilai $\mathrm{t}$ hitung sebesar 6,733 yang lebih dari t tabel $(1,960)$ serta nilai probabilitas $(0,000)<\alpha$ $(0,05)$. Sehingga dapat dijelaskan bahwa return on aset $(R O A)$ perusahaan terbukti berpengaruh positif dan signifikan terhadap nilai perusahaan (PBV) atau semakin besar return on aset maka akan mampu meningkatkan nilai perusahaan (PBV), hal ini ditandai dengan hipotesis yang terbukti. 


\section{Koefisien Determinasi}

Berdasarkan hasil perhitungan diperoleh nilai koefisien determinasi ( $R$ Square) sebesar 0,090 dan 0,382. Hal ini berarti besar variasi variabel struktur modal pada perusahaan automotive yang go publik di Indonesia yang dapat diterangkan oleh variasi variabel ukuran perusahaan (size) dan retunn on aset (ROA) adalah sebesar 9 $\%$, sedangkan sisanya sebesar $91 \%$ dipengaruhi oleh variabel lain di luar model penelitian. Pada variasi variabel nilai perusahaan pada perusahaan automotive yang go publik di Indonesia yang dapat diterangkan oleh variasi variabel ukuran perusahaan (size), retunn on aset (ROA) dan debt to equity ratio (DER) adalah sebesar 38,2\%, sedangkan sisanya sebesar $61,8 \%$ dipengaruhi oleh variabel lain di luar model penelitian.

\section{KESIMPULAN}

1. Struktur modal (debt to equity ratio) terbukti mempunyai pengaruh yang positif dan signifikan terhadap nilai perusahaan $\left(\mathrm{H}_{1}\right.$ terbukti).

2. Ukuran perusahaan (size) terbukti mempunyai pengaruh yang positif dan signifikan terhadap struktur modal $\left(\mathrm{H}_{2}\right.$ terbukti).

3. Ukuran perusahaan (size) terbukti mempunyai pengaruh yang positif dan signifikan terhadap nilai perusahaan $\left(\mathrm{H}_{3}\right.$ terbukti).

4. Profitabilitas (return on aset) terbukti tidak mempunyai pengaruh yang positif dan signifikan terhadap struktur modal $\left(\mathrm{H}_{4}\right.$ tidak terbukti).

5. Profitabilitas (return on asset) terbukti mempunyai pengaruh yang positif dan signifikan terhadap nilai perusahaan $\left(\mathrm{H}_{5}\right.$ terbukti).

6. Besar variasi variabel struktur modal pada perusahaan automotive yang go publik di Indonesia yang dapat diterangkan oleh variasi variabel current ratio $(C R)$ dan retunn on equity $(R O E)$ adalah sebesar $9 \%$. Variasi variabel nilai perusahaan pada perusahaan automotive yang go publik di Indonesia yang dapat diterangkan oleh variasi variabel current ratio $(C R)$, retunn on equity $(R O E)$ dan debt to equity ratio (DER) adalah sebesar 38,2\%.

\section{Kelemahan dan Agenda Mendatang}

1. Obyek penelitian masih membatasi pada sektor automotive dan allied products yang go publik di Indonesia. Penelitian ini tidak memasukkan sektor - sektor riil atau keuangan (perbankan).. 
2. Penelitian mendatang mengarahkan pada obyek penelitian yang lebih luas dengan mengambil obyek - obyek sektor lainnya

3. Penelitian ke depan perlu dengan menambah atau memasukkan konstruk atau variabel lain yang dapat berpengaruh terhadap nilai perusahaan.

\section{DAFTAR PUSTAKA}

Apsari. Idha Ayu., Dwiatmanto dan Devi Farah Azizah., 2015., Pengaruh Return On Equity. Net Profit Margin. Debt To Equity Ratio. Dan Longterm Debt To Equity Ratio Terhadap Price Book Value (Studi Pada Perusahaan Sub Sektor Makanan dan Minuman yang Terdaftar di Bursa Efek Indonesia Periode Tahun 20102013)., Jurnal Administrasi Bisnis (JAB)|Vol. 27 No. 2 Oktober 2015

Ayuningtias. Dwi dan Kurnia., 2013., Pengaruh Profitabilitas Terhadap Nilai Perusahaan : Kebijakan Dividen Dan Kesempatan Investasi Sebagai Variabel Antara., Jurnal Ilmu dan Riset Akuntansi., Volume 1 Nomor 1. Januari 2013

Brigham. Huston., 2011., Dasar - Dasar Manajemen Keuangan., (Buku 1)., Salemba Empat., Edisi 11 Jakarta

Dewi. Ni Kadek Sugiani Merta dan Badjra. Ida Bagus., 2013., Pengaruh Likuiditas. Profitabilitas. Tangibility Assets. Ukuran Perusahaan Dan Pajak Terhadap Struktur Modal., Fakultas Ekonomi., Universitas Udayana., Bali.

Dwiaji. Y.C. 2011. Analisis Pengaruh Profitabilitas terhadap Keputusan Keuangan dan Dampaknya Pada Nilai Perusahaan Industri-Industri yang Terdaftar Di PT Bursa Efek Indonesia (BEI) Tahun 2004-2009. AAT Professional Journals. http://aatprofessionaljournals.blogspot. com. Diunduh 28 Mei 2016.

Fakhruddin. M. dan M.S. Hadianto. 2011. Perangkat dan Model Analisis Investasi di PasarModal. Elex Media Komputindo. Jakarta.

Ghozali. Imam., 2013., Aplikas Analisis Multivariate dengan Program IBM SPSS 21 Update PLS Regresi., Badan Penerbit Universitas Diponegoro., Semarang.

Gill, Amarjit. and Obradovich, John D. 2012. The Impact of Corporate Governance and Financial Leverage on the Value of American Firms. International Research Journal of Finance and Economics.

Hamidy. Rahman Rusdi., 2014., Pengaruh Struktur Modal Terhadap Nilai Perusahaan Dengan Profitabilitas Sebagai Variabel Intervening Pada Perusahaan Properti dan Real Estate di Bursa Efek Indonesia., Tesis., Fakultas Ekonomi., Universitas Udayana., Bali.

Hermuningsih. Sri., 2012., Pengaruh Profitabilitas. Size Terhadap Nilai Perusahaan Dengan Sruktur Modal Sebagai Variabel Intervening., Jurnal Siasat Bisnis., Vol 16 No 2., Juli 2012 
Hermuningsih. Sri., 2013., Pengaruh Profitabilitas. Growth Opportunity. Sruktur Modal Terhadap Nilai Perusahaan Pada Perusahaan Publik di Indonesia., Buletin Ekonomi Moneter dan Perbankan. Oktober 2013

Husnan Suad dan Pudjiastuti., 2012., Dasar - Dasar Manajemen Keuangan., UPP STIM YKPN., Edisi 6., Yogyakarta.

Ichwan, Fith Yuniar dan Widyawati, Dini., 2015., Pengaruh Ukuran Perusahaan, Struktur Aktiva Dan Profitabilitas Terhadap Struktur Modal., Jurnal Ilmu dan Riset Akuntansi., Vol 4 No 6

Joni dan Lina. 2010. Faktor-Faktor yang Mempengaruhi Struktur Modal. Jurnal Bisnis dan Akuntansi. Vol.12. No.2. Agustus 2010. Pp: 81-96.

Mahendra. Alfredo Dj., Luh Gede Sri Artini., Suarjaya. A.A Gede., 2012., Pengaruh Kinerja Keuangan Terhadap Nilai Perusahaan pada Perusahaan Manufaktur di Bursa Efek Indonesia., Jurnal Manajemen. Strategi Bisnis. dan Kewirausahaan Vol. 6. 131 No. 2 Agustus 2012., Universitas Udayana. Bali.

Martikarini. Nani., 2014., Pengaruh Profitabilitas. Kebijakan Hutang. Dan Dividen Terhadap Nilai Perusahaan Manufaktur Yang Terdaftar Di Bursa Efek Indonesia Periode 2009-2011., Fakultas Ekonomi Jurusan Akuntansi., Universitas Gunadarma., Jakarta

Naceur, Samy Ben. and Goaied, Mohamed. 2002. The relationship between dividend policy, financial structure, profitability and firm value. Applied Financial Economics. 12: 843-849

Nofrita. Ria., 2013., Pengaruh Profitabilitas terhadap Nilai Perusahaan dengan Kebijakan Deviden sebagai Variabel Intervening (Studi Empiris pada Perusahaan Manufaktur yang Terdaftar di BEI)., Fakultas Ekonomi Universitas Negeri Padang

Priyatno. Duwi 2012. Olah Data Statistik Dengan SPSS. Yogjakarta: Penerbit Andi.

Riyanto. Bambang., 2010. Dasar - Dasar Pembelanjaan Perusahaan. Edisi 4. Yayasan Penerbit Gajah Mada. Yogyakarta

Rodoni. Ahmad dan Herni Ali. 2010. Manajemen Keuangan. Mitra Wacana Media., Jakarta.

Sartono. Agus., 2009., Manajemen Keuangan : Teori dan Aplikasi., (Edisi 4)., BPFE., Yogyakarta

Soliha, E dan Taswan. 2002. Pengaruh Kebijakan Hutang Terhadap Nilai Perusahaan Serta Beberpa Faktor yang Mempengaruhinya. Jurnal Bisnis dan Ekonomi.

Sujoko dan Subiantoro. 2007. Pengaruh Kepemilikan Saham. Laverage. Faktor Intern dan Faktor Ektern Terhadap Nilai Perusahaan (Studi Emperik Pada Perusahaan Manufaktur di Bursa Efek Jakarta). Jurnal Manajemen dan Kewirausahaan. 9 (1). 41-48.

Van Horne. James C. dan Wachowicz. John M., 2013., Prinsip - prinsip Manajemen Keuangan (buku 2) Edisi 13., Salemba Empat. Jakarta 
Wahyuni. Tri., Ernawati. Endang., Murhadi. Werner., 2013., Faktor - factor yang Mempengaruhi NIlai Perusahaan di Sektor Property. Real Estate \& Building Construction yang terdaftar di Bei Periode., 2008 - 2012., Calyptra : Jurnal Ilmiah Mahasiswa Universitas Surabaya. VOl 2 no 1 (2013)

Wardani. Mustika., 2015 Analisis Pengaruh Profitabilitas. Likuiditas dan Struktur Aktiva Terhadap Struktur Modal pada Perusahaan Manufaktur yang Terdaftar di BEI Tahun 2011-2013., Program Magister Manajemen., Universitas Muhamadyah Surakarta., Surakarta

Yusrianti. Hasni., 2013., Pengaruh Tingkat Profitabilitas. Struktur Asset. dan Growth Opportunity Terhadap Struktur Modal Pada Perusahaan Manufaktur yang Telah Go Public Di Bursa Efek Indonesia., Laporan Penelitian Dana Fakultas Ekonomi Unsri. Surakarta. 